DOI: 10.14526/2070-4798-2019-14-3-69-72

\title{
Psychological aspects of training young hockey players
}

\author{
Natalya N. Romanova*, Yan V. Latyushin, Dmitriy A. Dyatlov, Vladislav A. Kuliev \\ Ural State University of Physical Culture \\ Chelyabinsk, Russia \\ ORCID: oooo-0002-6373-6096, romanova-natasha@mail.ru* \\ ORCID: oooo-0oo3-1968-2315, valeas1@yandex.ru \\ ORCID: 0ooo-0002-0962-4704, dokchel@mail.ru \\ ORCID: 0ooo-0oo1-8726-4505, romanova-natasha@mail.ru
}

\begin{abstract}
This article considers the problem of psychological aspects of training young hockey players. We substantiated the urgency and the importance of the studied process in the theory and practice of physical culture and sports. We showed the results of the survey among young hockey players concerning the features of their psychological training. The experimental results are analyzed, the psychological and pedagogical interpretation of the results is presented. Research methods. Scientific literature analysis, methods of mathematical statistics, survey, questionnaire, observation, conversation. Materials. The characteristics of psychological training among young hockey players were diagnosed on the basis of the verbal questioning, questionnaire survey and also during personal and group conversations. The questions for the questionnaire survey are selected taking into account the purpose of the experimental work. Results. In the course of personal and group conversations, we diagnosed the difficulties of the psychological orientation among young hockey players. Completely all respondents mentioned lack of information from the training staff concerning psyhology of sport, the absence of independent unit of psychological training in the training and competitive process and as a result, unsatisfactory result of the team in the season. Conclusion. Different aspects of psychological training inclusion into the training and competitive process, directed toward resource potential revelation of each athlete, realized during group training and concultant activity and the offered material consideration by each athlete would help young hockey players to realize their abilities in playing practice more effectively, operatively and consistently.
\end{abstract}

Keywords: psychological training, young hockey players.

For citation: Natalya N. Romanova*, Yan V. Latyushin, Dmitriy A. Dyatlov, Vladislav A. Kuliev. Psychological aspects of training young hockey players. Russian Journal of Physical Education and Sport. 2019; 14(2): 69-72. DOI: 10.14526/2070-4798-2019-14-3-69-72

\section{INTRODUCTION}

The dynamics of events in modern hockey places high demands on the personality of the players regardless of their age, competitive experience and playing role. Very often having almost the same level of physical, technical, functional and tactical readiness, a player has lower psychological readiness indices, than his opponent.

Young hockey players feel great pressure since their childhood. This pressure is connected with tight schedule and the desire of a coach (administration of the club) to achieve maximum possible results in each match, in each part of the game. All these things have a great influence on children's psyche, form specific character traits, which sometimes develop till accentuated behavior, influence emotional and psychic state, preventing personal and professional potential improvement.

Pressing in terms of each player is increased by the specificity of hockey as a game. Not all players are included into the first team depending on the result of individual game, stability of performance during competitions, effectiveness of the held changes. Another reason for stress appearance is the situation when the player from the first team is injured and quickly replaced by another player. In such situation the replaced player can be deprived of the opportunity to play in the first team.

One of the most important categories in terms of psychological training of young hockey players, in our opinion, is emotions control. As we mentioned it earlier, in physical culture and sports activity it is important to work constantly with the states. Emotions, feelings understanding provides more effective training process realization. Controlling stress, caused by different reasons (in general by competitive activity, locally by pre-start state, comfortable environment change in terms the increased load of the training camps and etc.), would be more effective in case of competent diagnostics of the stress reasons, the peculiarities of its process and its possible consequences [8, p. 188]. 
We considered the importance of psychological aspects in the process of athletes training $[5 ; 6 ; 7$; 8]. Some scientists also underline the importance of studied by us psychological unit of training athletes of different qualification $[1 ; 2 ; 3 ; 4 ; 9]$.

Attention paid to psychological training of athletes would help to achieve the desired stable result, necessary position in a fixture list, guarantees playoff qualification for a team and gives an opportunity for a team to be in terms of Shootout games for a long- time period, showing necessary professional level of the game.

\section{MATERIALS AND METHODS}

Experiment was held on the basis of Municipal budgetary establishment "Sports school "Metallurgsport" in Chelyabinsk". 28 young hockey players of different playing role took part in season 2018-2019.

The research methods were the following: scientific literature analysis, methods of mathematical statistics, survey, questionnaire survey, observation, conversation method.

Mentioned above methods showed the importance of studied by us side of training athletes, revealed the range of difficulties and a problem field for further experimental work. Let's consider practical use of the mentioned above methods.

\section{RESULTS AND DISCUSSION}

During the conversation with the players of the team, further questionnaire survey we revealed the main difficulties of young hockey players during the process of training and performance at competitions. Very often athletes mentioned the features of prestart fever $(89,2 \%)$ and pre-start apathy $(7,1 \%)$. Only 3,7 \% of players mentioned stability of own results both at the games and during the training process.

We specified the following aspects of young hockey players' psychological training:

- if the training staff provides psychological training in general;

- if the theory concerning emotional and psychic state diagnostics, correction and control is offered;

- if there are lessons of the received knowledge practical mastering in the sphere of sport psychology;

- if hockey players receive personal recommendations from coaches concerning negative emotions and their consequences leveling;

- if the coaches explain the team how to cope with negative emotions, fear, anger, offence, sense of a guilt, shame, sorrow, scorn and others;

- if the coaches recommend the information about the techniques, which can help players to ignore or prevent opponent's provocations;

- if coaches organize individual and group consultations concerning the questions of sports psychology taking into account individual characteristics of each player;

-if attention is paid to the tasks fulfillment for team building, conflicts analysis and elimination;

- if the training staff give information concerning the techniques of pre-start states regulation.

Almosteach playerdenied availabilityofnecessary information from coaches, tasks and conversations concerning the mentioned topics. Hockey players only mentioned that sometimes coaches offer to get rid of fear by means of power techniques. We agree with the coaches that physical reaction of fear is an effective technique. But its disadvantage is in a short-term effect and in diagnostics absence of the reason for fear, which increases emotional and physical powers consumption of young athletes.

We should also mention that it is insufficient to consider psychological aspects right before the start. Psychological support of sports activity includes athlete's state and behavior control:

- before the training lesson;

- during exercises fulfillment at the training;

- between the training lessons;

-in the definite training period;

- before the competition;

- right before the start;

- during the intervals between competitive exercises;

- after the competitions.

We also revealed that the mentioned parts are not reflected in sports staff training.

Oral survey method (among hockey players and their parents) also showed that parents and young athletes are interested in studying psychological aspects of the chosen kind of sport. Parents are worried about their children's behavior, as aggression demonstration (necessary in hockey), quickly changing actions of children cause parents' negative emotional and psychic states, such as frustration, stress, anxiety, worry, dismal mood, unreasonable fear, guilt, shame, tiredness (of constantly appearing situations), apathy, puzzlement, dissatisfaction, sense fatality, oppression, distraction, despair and others.

Used by us research methods proved the presence of difficulties in the practice of hockey with a puck. 


\section{CONCLUSION}

In the practice of modern sport not much attention is paid to psychological training. Very often psychological advantage in terms of equal abilities of the opponents plays the crucial role. Hockey being dynamic and cruel kind of sport has a specific influence on individual characteristics of players. In terms of maximum attention distribution between the opponent's actions prediction, work of the whole team, quick puck movement, comments of team partners and training staff it is important to make effective decisions, taking into account lack of time and be responsible for them. In this situation special role play volitional qualities of players, the ability to take a punch in physical and psychological understanding and stability of axiological orientations.

Very often coaches view with some skepticism the work of sports psychologists, though themselves don't know information and don't have time for independent specialized players training. Practice shows that the demands placed on young hockey players increase, there is some domination of teachers' position, but coaches themselves are not always ready to give athletes necessary knowledge concerning self-control during trainings and games, before requiring results.

Thus, our research work proves the urgency and timeliness of experimental work organization connected with psychological training of young hockey players.

\section{REFERENCES}

1. Alekseev A. V. Preodolet' sebya! [To overcome yourself!]. Moscow: Physical culture and sport. 1985: 192 (In Russ.).

2. Latyushin Ya. V., Karakaeva Zh.Kh. Problems of psycho-functional states of 20-21 yearold skiers during pre-competitive period. Materialy regional'noj nauchno-metodicheskoj konferencii kandidatov v magistry: fizicheskaya kul'tura, sport, turizm: nauka, obrazovanie, tehnologii [Material of regional scientific-methodical conference of candidates for a master's degree; physical culture, sport, tourism: science, education, technologies]. Chelyabinsk: UralSUPC, 2017: 123-127 (In Russ.).

3. Rendikova A.V. Possibilities of students psychological support optimization at UralSUPC. Optimizaciya uchebno-vospitatel'nogo processa v obrazovatel'nyh organizaciyah fizicheskoj kul'tury: materialy XXVIII regional'noj nauchnometodicheskoj konferencii [Educational-upbringing process optimization in physical culture educational establishments: materials of the XXIX regional scientific-methodical conference]. Chelyabinsk: UralSUPC. 2019: 185-187.

4. Rendikova A.V. Psychological maintenance of students from Ural State University of Physical
Culture. Optimizaciya uchebno-vospitatel'nogo processa v obrazovatel'nyh organizaciyah fizicheskoj kul'tury: materialy XXVIII regional'noj nauchnometodicheskoj konferencii [Educational-upbringing process optimization in physical culture educational establishments: materials of the XXVIII regional scientific-methodical conference]. Chelyabinsk: UralSUPC. 2018: 147-148.

5. Romanova N.N. Methodology of emotional states reflection development among the future physical culture teachers. Pedagogikopsihologicheskie I medico-biologicheskie problemy fizicheskoj kul'tury I sport = Pedagogicopsychological and medico-biological problems of physical culture and sport. 2013; 8(4): 161-166 (In Russ., In Engl.)

6. Romanova N.N. Methodical peculiarities of emotional states reflexion development among the future physical culture teachers. Teoriya I praktika fizicheskoj kul'tury = Theory and practice of physical culture. 2015; 5: 35-37 (In Russ., In Engl.).

7. Romanova N.N. Psychological-pedagogical characteristics of emotional states reflexion development process among the future physical culture teachers in terms of the integral approach. Celostnyj podhod $\mathrm{k}$ professional'noj podgotovke vypusknikov vuza [An integral approach to professional training of higher educational establishments graduates]. Chelyabinsk: Ural Academy. 2015: 207-231.

8. Romanova N.N. Work with graphical product during emotional states reflexion development among the future physical culture teachers. Mezhdunarodnaya nauchnoprakticheskaya konferenciya gosudarstv uchastnikov SNG po problemam fizicheskoj kul'tury I sporta: material mezhdunarodnoj nauchnoprakticheskoj konferencii, Minsk, 27-28 maya 2010 [International scientific-practical conference of states CIS participants concerning the problems of physical culture and sport: material of the International scientific-practical conference. Minsk, May, 27-28, 2010]. BSUPC: Minsk. 2010; 2: 188191.

9. Khrisanfova N.V., Latyushin Ya.V. Nervous system characteristics study of athletes, who specialize in average distance running. Problemy sovremennogo pedagogicheskogo obrazovaniya. 2017; 57-7: 299-305 (In Russ.).

10. Agel J., Harvey E.J. A 7-year review of men's and women's ice hockey injuries in the NCAA. Canadian Journal of Surgery. 2010; 53(5): 319-323.

11. Darling S.R., Schaubel D.E., Baker J.G., Leddy J.J., Bisson L.J., Willer B. International versus unintentional contact as a mechanism of injury in youth ice hockey. British Journal of Sports Medicine. 2011; 45: 492-497.

12. International Ice Hockey Federation. Rule 
book 2010-2014. 2010. URL: http://www.iihf.com/ ihf-home/sport/iihf-rule-book.html.

13. Marino G.W., Potwin J. Impact characteristics of two types of hockey arena boards.
International Society of Biomechanics in Sport. 2002: 614-617. URL: http://w4.ub.uni-konztanz. de/cpa/article/viewFile/857/761.

\section{Submitted: 07.08.2019}

Author's information:

Natalya N. Romanova - Candidate of Pedagogics, Ural State University of Physical Culture, 454091, Russia, Chelyabinsk, Ordzhonikidze str., House 1, e-mail: romanova-natasha@mail.ru

Yan V. Latyushin - Doctor of Biological Sciences, Ural State University of Physical Culture, 454091, Russia, Chelyabinsk, Ordzhonikidze str., House 1, e-mail: valeas1@yandex.ru

Dmitriy A. Dyatlov - Doctor of Biological Sciences, professor, Ural State University of Physical Culture, 454091, Russia, Chelyabinsk, Ordzhonikidze str., House 1, e-mail: dokchel@mail.ru

Vladislav A. Kuliev - Student, Ural State University of Physical Culture, 454091, Russia, Chelyabinsk, Ordzhonikidze str., House 1, e-mail: romanova-natasha@mail.ru 